\title{
THE ROLE OF SMALL TOWNS IN LOCAL PLACE MAKING
}

\author{
Bernadett Csurgó ${ }^{1}$, Boldizsár Megyesi ${ }^{2}$
}

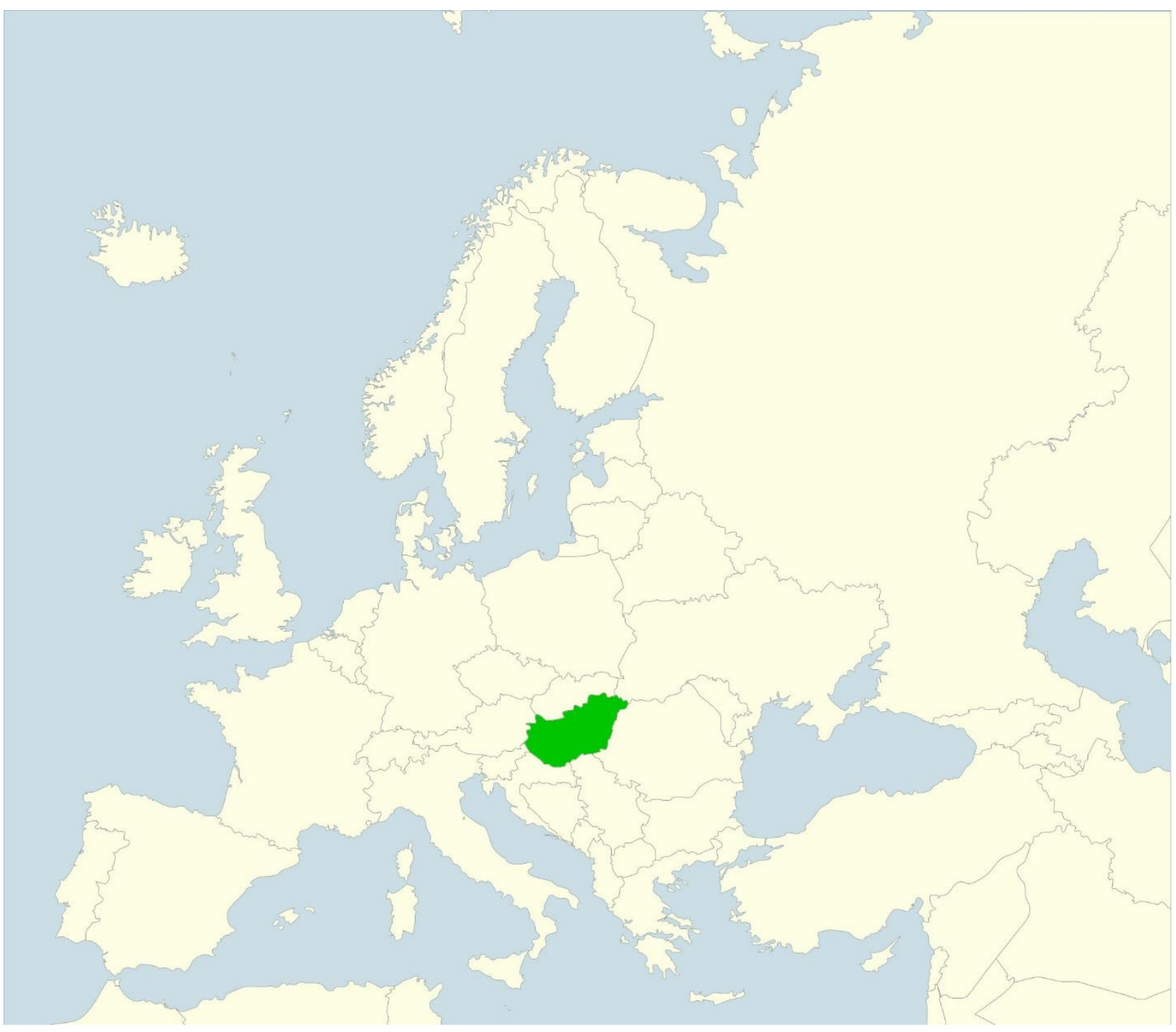

\footnotetext{
${ }^{1}$ senior research fellow, Institute for Sociology of HAS Centre for Social Sciences, Országház u. 30, H-1014 Budapest, Hungary; csurgo.bernadett@tk.mta.hu

${ }^{2}$ senior research fellow, Institute for Sociology of HAS Centre for Social Sciences, Országház u. 30, H-1014 Budapest, Hungary; megyesi.boldizsar@tk.mta.hu
} 
Abstract: Self-promotion and reinterpretation of local identity is becoming increasingly important in rural communities. Local identity building is succeeded very differently by rural municipalities and regions. The paper analyses the role of small towns in local identity creation. There are varying interpretations of places in Hungary as ways of achieving meaningful territorialisation. Small towns based on their leading and central position within the micro regions can dominate the place-making processes. Using the example of six Hungarian rural micro-regions we analyse how rural small towns position themselves by local image building. The aim of this paper is to investigate interactions between territorial position and innovative capacity of rural towns through the analysis of symbolisation process and image building. We purpose to introduce a concept of a place oriented approach and demonstrate its usefulness for analysis of rural innovation and place-based development. The case-studies are based on qualitative methods: document-analysis, semi-structured interviews, transect walking and participatory observation. The paper analyses the process of local community and identity building in six rural micro-regions. We seek to understand how small towns position themselves in place-making, the aim of 'placing' themselves in the territorial hierarchy of the settlements of micro region. Our results suggest that small towns play very different roles in local image building. Characteristics and territorial scope of local cultural heritage significantly determine the innovative capacity of small towns in local image building where there is a wide range of meanings procedures and processes of place-making.

Key words: small town, place-making, local identity, local image

Absztrakt: A vidéki közösségek számára önmaguk bemutatása és a helyi identitás újraértelmezése egyre fontosabbá válik. A helyi identitásépítést a különböző vidéki települések és térségek eltérő módon valósítják meg. Tanulmányunk a vidéki kisvárosok szerepét vizsgálja a helyi identitás alakításában. Magyarországon eltérő értelmezései vannak a helynek, mint a jelentést adó territorializáció megvalósulási formájának. A kisvárosok a kistérségeken belüli vezető szerepükből és központi pozíciójukból adódóan a helyi adottságokra építő fejlesztési folyamatokban is domináns szerepet kaphatnak. Hat magyarországi kistérségi esettanulmány segítségével azt elemezzük, hogy a kisvárosok hogyan pozícionálják önmagukat a helyi imázsépítés folyamatában. A tanulmány célja, hogy a szimbolizációs folyamatok és az imázsépítés elemzésén keresztül feltárja a kisvárosok területi pozíciója és innovatív kapacitása közötti kapcsolatokat. Szeretnénk bevezetni egy „hely központú” (place-based) megközelítést, és bizonyítani alkalmazhatóságát a helyi innováció és a helyre építő fejlesztések elemzésében. Az esettanulmányok kvalitatív kutatási módszerek; dokumentumelemzés, félig strukturált interjúk, terepbejárás és résztvevő megfigyelés segítségével készültek. A tanulmány a helyi közösség és identitásépítés folyamatát vizsgálja hat vidéki kistérségben. Szeretnénk megérteni, hogy a vidéki kisvárosok milyen pozíciót foglalnak el a hely központú fejlesztésekben, és hogy a területi hierarchiában elfoglalt pozíció hogyan határozza meg a vidéki városok szerepét ebben. Eredményeink azt mutatják, hogy a kisvárosok nagyon eltérő szerepet tölthetnek be a helyi imázsépítésben. A helyi kulturális örökség jellegzetességei és térbeli elhelyezkedése nagymértékben meghatározza a kisvárosok innovatív kapacitását a helyi imázsépítésben, amelyen belül a jelentést adó folyamatoknak és a helyre építő kezdeményeseknek nagyon sokféle formája létezik.

Kulcsszavak: kisváros, helyre építő fejlesztés, helyi identitás, helyi imázs 


\section{Introduction}

A major concern of work in rural sociology in recent decades has been to analyse why certain development activities happen in certain places. Thus, there is an increasing interest in rural studies on place-based development, rural place-making, localisation etc. (Dessein et al., 2015). Parallel with these place based approaches rural development policy has experienced an increased focus on culture-based development. Cultural heritage, tourism, cultural industries, creativity and design has been focused in rural research (Bessière, 1998; Ray, 1998). However less is known about the role that small towns play in rural development and especially in cultureled rural place-making in their micro-region. The aim of this paper is to investigate interactions between territorial position and innovative capacity of rural towns through the analysis of symbolisation process and image building in six rural micro-regions. We focus on the role that small towns play in rural place making and we purpose to assess the linkages between small towns and the surrounding regions, in order to discover which characteristics of small towns can determine their role in place making process. We purpose to introduce a concept of a place oriented approach and demonstrate its usefulness for analysis of rural innovation and placebased development.

We advance the body of rural sociology literature by focusing on the role of small towns in rural micro regions in place-making. A brief summary on the literature of place based development and culture-led development policies is presented in the first part of the paper. We also focus on the results of rural studies on small towns. Then we present our methods and using examples from our case studies we present the factors and resources as like as analytical dimensions, influencing the place-making process and the role of small towns in them.

\section{Theoretical background}

The increasing focus on cultural components in rural development studies is rooted on the socalled 'cultural turn' of rural research which means that the poststructuralist approach became one of the mainstream approach in contemporary rural studies (Cloke, 1997; Halfacree, 2007, 1995, 1993; Jones, 1995; Mormont, 1990; Phillips, 2005, 1993). In the spirit of the 'cultural turn' the rural places can be understood as a cultural and social constructs or representations of the place (Halfacree, 1993). Rural studies started to reinterpret 'rural' according to postmodern and constructivist approach and more serious focus on the meanings and representations of rural places and on their emergent identities were resulted (Cloke, 1997; Cloke et al., 1998; Halfacree, 1995; Hopkins, 1998). Culture has become a significant resource in local development policy. Culture became an essential factor in the development of rural communities. Regional development and culture policy have merged. Rural regions and places intensively started to revitalise their cultural heritage and to build new image and local identity. (Ilmonen, 2015). Changing role of small town is rural regions proved by many studies (Heffner) are also may represented in place making process.

Place-making and place-based development purpose and contribute to the changing or strengthening the identity of place such as local and regional identities. Place-making is the symbolic as well as material construction of the place where the notion of place identity is central (Dunn et al., 1995). Many scholars prove that the local image building and symbolisation process can built strong linkages of the image to the place identity (Bessière, 1998; Csurgó, 2014; Csurgó and Megyesi, 2015; Dessein et al., 2015; Kovách, 2012; Paasi, 2003)

Paasi (2003) reviewed the scientific discourses on regional identity. He stated that traditional view of regional identity based on the notion of harmony between region and its inhabitant. Regional and place identity and their meanings for their inhabitants are important topics of human geography and also for rural studies. Paasi shows that current discourses on region and place emphasise that regional and place identity rooted on contested social constructions and processes. Place can be regarded differently by different social classes, gender, ethnic groups, etc. Thus places and place identities are contested and Paasi highlighted that the current discourse on place and identity are also contested. He also argues that regional identity is a key element of place-making such as the making of regions as social spaces. Using the theory of 
Castells (1997) Paasi pointed out that regional identity 'can be a constitutive element of localized resistance to globalization' (Paasi, 2003, p. 3) and he also stated that regional identity typically regarded as a productive forces of regional developments. Production of territorial boundaries, symbols and institutions are the results of regional identity as an interpretation process (Paasi, 2003).

Symbolisation of place constitutes the process of identification in that stakeholders reconstruct and represent their place (Dessein et al., 2015). Symbolisation of place is one of the main dimension of place making.

There is also an increasing focus on endogenous forms of development in rural sociological literature nowadays (Brunori and Rossi, 2000; Dessein et al., 2015; Halseth et al., 2010; Ray, 2006, 1998; van der Ploeg and van Dijk, 1995). This kind of development lies in the capacity and skills of local people. It creates a bottom-up, community-led solutions of social and economic problems (Ray, 2006, 1998). Place-based development strategies are part of this endogenous development process. Ray (1998) states that people in rural areas can revive or protect their economic and social well-being through the strategic use of local culture and the pursuit of local participative democracy. Parallel with place-based and endogenous approach of rural development scholars also highlight the increasing importance of cultural component of territorial and rural development (IImonen, 2015; Radcliffe, 2006; Ray, 1998). Culture has been taking place in regional development strategies from the 1990's and cultural and cultural heritage has been regarded as beneficial effect on local development. Dessein et. al. (2015) state that the ways of cooperation, organisations and planning as the cultural characteristic of institution of local institutions are crucial in place based development. The importance of institutional dimension of place making is proved by them.

Image making and identity building are the centre in culture-led development policies (Bessière, 1998; Ilmonen, 2015; Kivitalo et al., 2015). Lysgard (2016) argues that heritage, traditions and community practices are in the forefront of culture-led rural strategies in rural places while urban places take more attention to creative industries, attractiveness and place marketing. It refers to the marketing dimension of place making.

Both place-based and cultural-led rural development discourses emphasise the importance of local knowledges, local cultural characteristics, community capacity and social capital rather than the structural and economic characteristics of the locality (Halseth et al., 2010). Roles and functions of small towns are determined by the changes in development processes (Ebrahimzadeh et al., 2012; Heffner and Solga, 2006; Lysgård, 2016).

Small towns have special roles in rural development. They have intermediate position between big cities and rural settlements. Their role and position in local development is strongly determined by the level of small towns' integration into their neighbouring rural areas. Heffner and Solga (2006) analyse the economic integration of small towns to rural areas. They found that the size and type of towns and their surrounding areas significantly determine the integration of small towns to rural surroundings. Small towns in agricultural regions are more strongly locally integrated that town in tourist areas and in metropolitan areas (Heffner and Solga, 2006).

Ebrahimzadeh et al. (2012) summarize the role of small towns in territorial and spatial development theories. They present that in the 1970's scholars of neoclassical spatial development school emphasised that small towns can help in the development of rural areas. The Central Location Theory by Johnson is the initial work from this school, he argued that rural towns are identified in relation with other settlements can fill the gap between big cities and villages and can provide essential conditions for development. According to his theory small towns are synonymous with central locations. Johnson theory was further developed by Rondinelli as the "Urban Function in Rural Development" (UFRD) theory. Rondinelli confirmed that small town as rural centres assume urban functions and link rural areas to regional development projects. Ebrahimzadeh et al.(2012) highlighted that it has been an increasing focus on the development of small towns since the early 80's. They also stated that the role of small towns in rural development is significantly determined by the center-periphery position as stage of development of the region and country. According to this center-periphery theory in the stage of pre- 
industrialism small towns has strong power and even parasitic growth in locally but they do not play any role in regional development. In the beginning of industrialisation and in the stage of industrialisation small towns are weakened. Finally in the stage of post-industrialization small towns regain their position in urban hierarchy and became the drivers of rural development. The last theory presented by Ebrahimzadeh et al.(2012) is the rural-urban development theory which criticise the central focus of economic growth and emphasise the social aspects of development. Decentralisation, public participation and local characteristics get central focus in this theory as well as in development planning. Small towns are the best examples for the realisation of this theory as Ebrahimzadeh et al. (2012) stated.

Lysgard (2016) also argued that actual cultural development strategies of small towns and rural places could be explained through the analysis of local actors, power relations, demands and interests. He stated that the cultural policy of small towns and rural places can be understood and studied as a local process and not just as an outcome or flow of global processes.

The above presented body of literature bring us to the following three dimensions of place making which will be involved in the analytical framework of this paper to explore the role of small town in place making. These are (1) symbolisation of place, (2) institution building and (3) marketing of place. These dimensions are overlapping and circulating but also present the building process of place making. Figure 1 presents the dimensions of the place making process, and relationship among the dimensions.

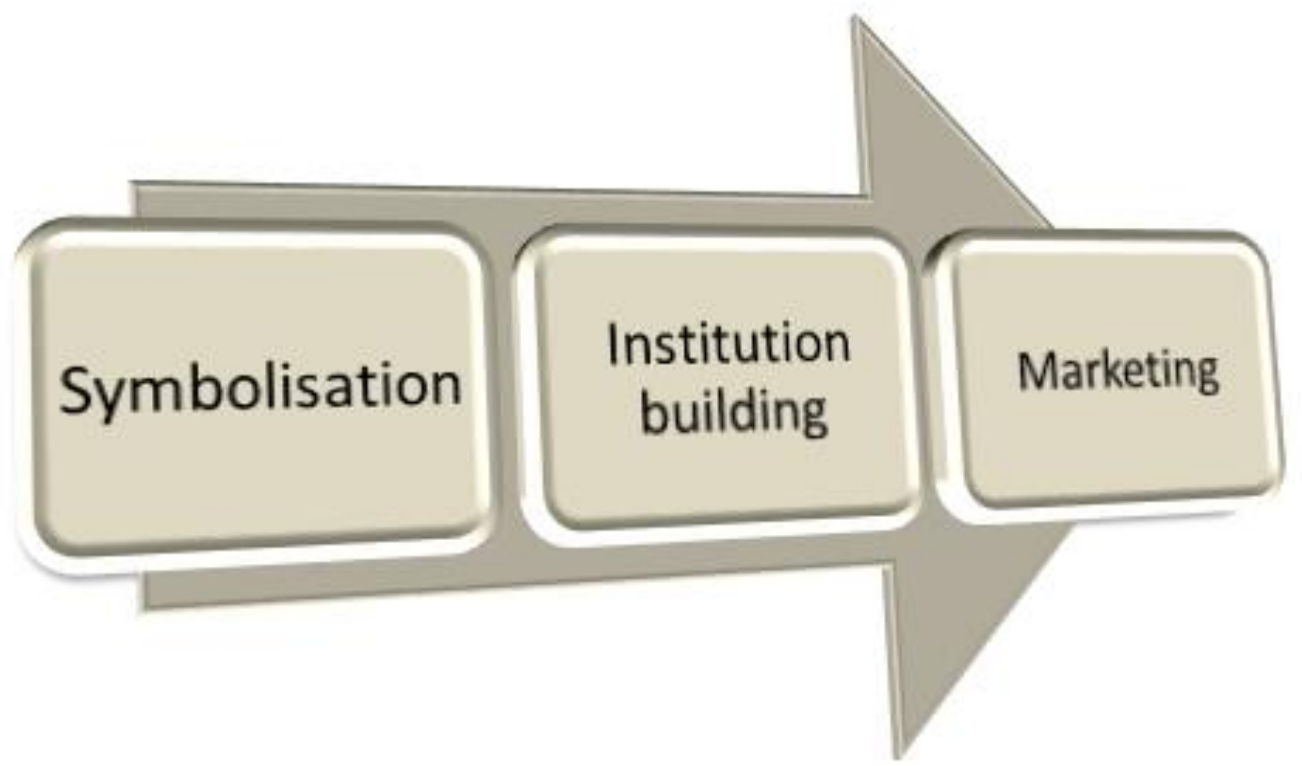

Fig 1. Dimensions of place making process.

This paper focus on rural places and especially small towns and their roles on place-making as like as interpretation process of place and place identity which contribute to a culture-led local development. We seek to explore whether structural characteristics of settlements as like as central position can inflow the position and participation of different settlements inside the local place-making. We purpose to present the differences - if there is any - regarding local knowledges, local cultural characteristics, community capacity between small towns and villages inside micro regions and their impact on local place-making as culture-led local development. Can small towns play an effective role in place-making of rural areas is the main question to what this paper is purposed to response. 


\section{Methods}

The paper is based on the secondary analysis of six case studies ${ }^{3}$. The case studies are based on qualitative methods: document-analysis, semi-structured interviews, transect walking and participatory observation (Kvale, 1994). In each case study areas we conducted at least 25 semistructured interviews with local decision-makers, members of local civic associations, farmers and local entrepreneurs. We used transect walking and participatory observation to better understand the context of the research and to validate our results. The case-studies were conducted between 2014. November and 2015. December by the authors and students ${ }^{4}$.

In the following we shortly present the six case study areas: Fonyód, Kalocsa, Mezőtúr, Öriszentpéter - Örség, Vasvár, Zalaszentgrót micro regions. The location of studied small towns and their micro regions is presented in the following map.

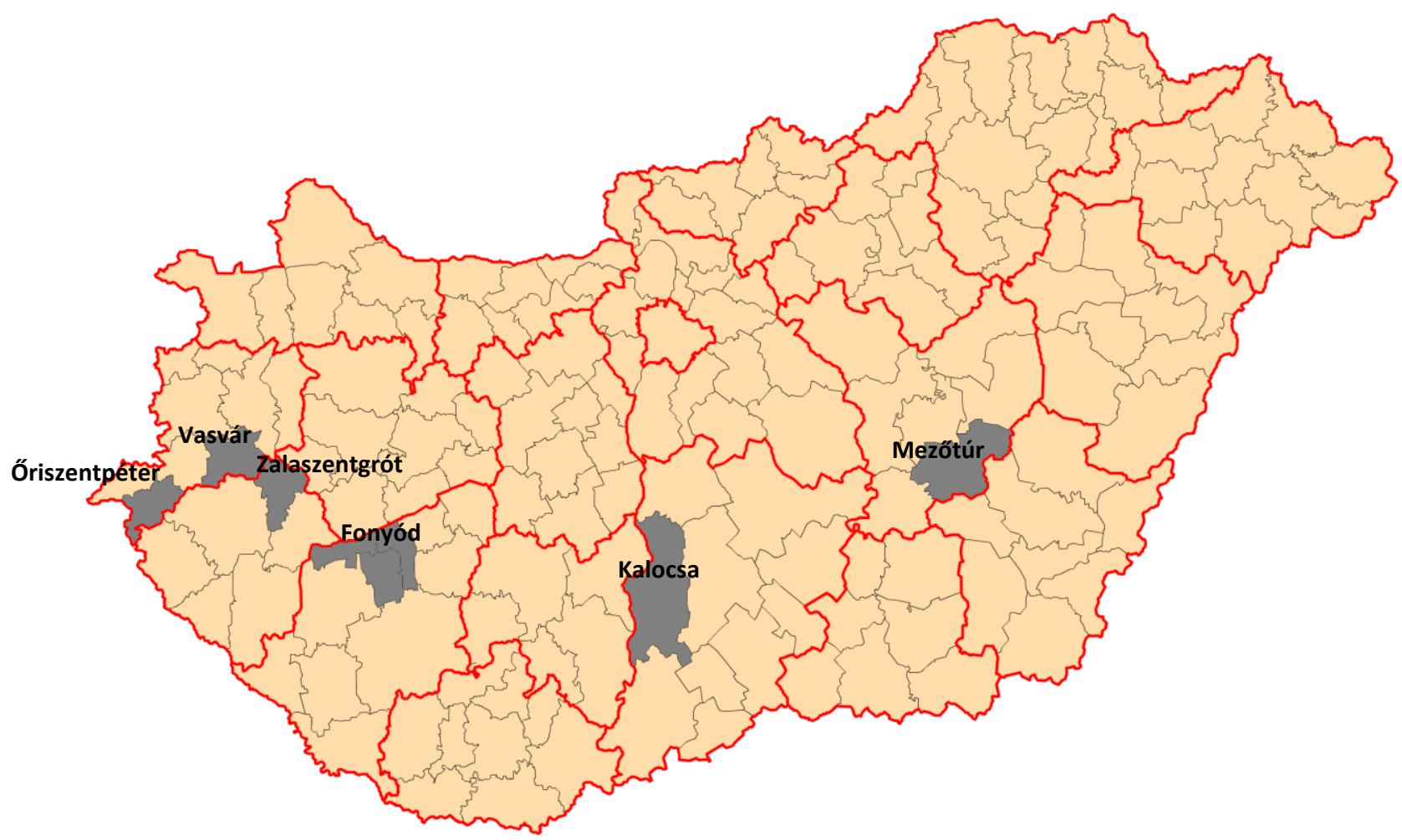

Fig 2. Location of studies small town and micro regions.

The Fonyód district is the second most developed according to social and economic indexes (Bublik and Nyeste, 2014), it is heterogeneous: the northern part, including the central town are important tourist destinations, thanks to the lake Balaton, while the southern part is a back-warded agricultural area. Originally the district was two independent micro-region, and the southern part was among the least developed ones.

Kalocsa district is located in the central part of Hungary, it is an economically and socially less developed district. The population decline is high in the villages, agriculture is important in the economy of the region while the tourism is characterised only for the town of Kalocsa.

Mezőtúr district is in the lower third of the development ranking list of districts in Hungary (Bublik and Nyeste, 2014). It is characterised by depopulation and recession. The most important

\footnotetext{
${ }^{3}$ The paper is based on the case studies of the "Living from the land" (OTKA 100682), "Cultural heritage and sustainable rural development" (OTKA 108628) and "Effects of rural policies..." (OTKA 11629) projects.

${ }^{4}$ We would like say thank you for their help in the field work for Viktória Bene, Mária Gulyás, László Lipcsei, Zsolt Mile, Anita Szatmári
} 
economic sector is the agriculture even if there are some industrial firms in the towns. Mezötúr district contents two towns. Tourism doesn't have any relevance in the local economy.

Örség is a part of a socially and economically developed district at the Western border of the country It is a remote rural area and the population decrease but the region has increasing temporary population thanks to the tourism. Tourism is very important in the area, which preserved its relative untouched character of the landscape till the change of the regime.

Vasvár is one of the least developed among the analysed districts, with around 14,000 inhabitants and a small rural centre. It has a unique natural environment. Its economy is characterized by agriculture and light industry, the ratio of commuters is high.

Zalaszentgrót is the third most developed district among the analysed ones, but compared to its region it is a small, remote area. Tourism has almost no relevance in the micro-region, although it has a spa, and several famous spas and the lake Balaton is in its vicinity.

Tab 1. Main characteristics of the case study areas.

\begin{tabular}{|c|c|c|c|c|c|c|}
\hline Dimension & Kalocsa & Vasvár & Zalaszentgrót & Fonyód & Örség ${ }^{5}$ & Mezőtúr \\
\hline $\begin{array}{c}\text { Economic character of the } \\
\text { area }\end{array}$ & $\begin{array}{l}\text { Remote } \\
\text { rural }\end{array}$ & $\begin{array}{l}\text { Remote } \\
\text { rural }\end{array}$ & Remote rural & $\begin{array}{l}\text { Peri- } \\
\text { urban }\end{array}$ & $\begin{array}{l}\text { Remote } \\
\text { rural }\end{array}$ & $\begin{array}{l}\text { Remote } \\
\text { rural }\end{array}$ \\
\hline Number of residents (2011) & 50468 & 13164 & 15343 & 33962 & 6671 & 27768 \\
\hline $\begin{array}{l}\text { Registered job seekers (2011) } \\
\qquad(\%)^{6}\end{array}$ & 10.6 & 8.8 & 9.9 & 11.9 & 5.0 & 12.4 \\
\hline $\begin{array}{l}\text { Number of nights spent }{ }^{7} \\
\text { (2015) }\end{array}$ & 2637 & 931 & 13511 & 73486 & 16852 & 847 \\
\hline $\begin{array}{c}\text { Number of settlements } \\
\text { (towns) }\end{array}$ & $21(3)$ & $23(1)$ & $20(1)$ & $21(4)$ & $22(1)$ & $5(2)$ \\
\hline
\end{tabular}

\section{An analytical framework to understand the role of small towns in place making}

The paper focuses on differences in the roles of rural small towns in place-making. It develops and tests an analytical framework by presenting three dimensions of place-making. The framework helps us to compare the role of rural small-towns in the process. We define the following three dimensions of place-making (see above) (1) symbolisation of place, (2) institutionalisation of place-making and (3) marketing of place. We use some contrasting types of rural small towns and their micro-regions as examples to present these dimensions, and compare the relationship between the rural small towns and the micro-region around them to highlight the differences of their innovative capacity. In this chapter we present the analysis of the cases and the detailed presentation of the analytical framework.

\section{Symbolisation of place}

The process of symbolisation is one of the central element of places making (Dessein et al., 2015). It contains the identification of the place through the main characteristics of the locality. Symbols and symbolic meaning of the place contribute and represent the sense of place. Symbolisation process is significantly determined by other sub-dimensions. In our analysis we defined the characteristics of the symbol and the visibility of the symbol. We defined three subcategories: the character of the symbol, the internal view and the publicity of the symbol; we also analysed whether the symbols are similar in the rural small town and the surrounding area.

\footnotetext{
${ }^{5}$ Here we use the statistical data of Öriszentpéter statistical micro region which covers the main part of Örség historical region.

6 (National Census 2011)

${ }^{7} \mathrm{KSH}$, Dissmeination Databse, Tourism \& catering (http://statinfo.ksh.hu/Statinfo/haViewer.jsp)
} 
The categories of the character of the symbol are the following: non-material (like: art or folk art motive) or natural value (eco-system service), or materialized (food or handicraft). The second sub-dimension of symbolization is linked to its visibility or publicity. The publicity of the symbol (the image-holder) has four categories: (1) internationally, (2) nationally or (3) locally well-known, and (4) unknown. In the analysis we refer to the similarities and differences between the symbols of the rural small town and the surrounding region, and the role these symbols play in placemaking. We also argue that the internal view of selected symbol or symbols is a crucial factor for the success of symbolization process. Thus we focus on whether the symbol of the region is accepted by locals or not. The following table shows the values and sub-dimensions of the symbolization of place dimension.

Tab 2. Understanding symbolization.

\begin{tabular}{|c|c|c|}
\hline Dimension & Sub-dimension & Values \\
\hline \multirow{4}{*}{ Symbolization of place } & Main characteristics of the symbol & $\begin{array}{c}\text { Non-material tradition } \\
\text { Materialized tradition } \\
\text { Natural value }\end{array}$ \\
\hline & Coverage of the symbol & $\begin{array}{l}\text { Partial; } \\
\text { Full. }\end{array}$ \\
\hline & Publicity & $\begin{array}{l}\text { Internationally well-known; } \\
\text { Nationally well-known; } \\
\text { Locally well-known; } \\
\text { Locally unknown }\end{array}$ \\
\hline & Internal view of the symbol & $\begin{array}{c}\text { Accepted by locals; } \\
\text { Not-accepted by locals; }\end{array}$ \\
\hline
\end{tabular}

In the six cases we analysed, we found non-material local traditions in the case of Vasvár, Mezőtúr, Örség and Fonyód district. The Vasvár case is interesting, as the actors not simply revived existing traditions, but aimed at inventing new local traditions such as castle tournament. In the case of Mezőtúr micro region common cultural identity of the municipalities is connected to the peasant traditions and Cuman past origin. The main symbol of the micro region became the historical origin. Mezőtúr micro region is a part of the historical and geographical region of Greater Cumania (Nagykunság). Most of the settlements of the micro region except Mezőtúr town are so-called Cuman settlements where Cumans were settled in the 13th century. Cuman origin became the core element of the image building process in the micro region, they purpose to provide a common touristic image and the group of attractions covering the whole Greater Cumania region. According to this goal Mezőtúr town tries to present itself as a part of the Cuman settlements even if originally the town has never been a Cuman place. In the case Örség region the regional symbol is rooted on the idyllic view of the whole Örség region. Örség has the meaning of rural idyll and authenticity both for locals and outsiders which is based on the local historical and ethnographic origins. Kalocsa image based on local folk-art traditions including materialised and non-materialised elements. Folk-dance as non-materialised tradition of Kalocsa and its region has the strongest symbolic meaning from the non-materialized traditions of the region. All the settlements of the region have local folk-dance groups. Folk-dance is a living tradition which has strong symbolic meaning and which is also an important driver for the community integration.

Materialized traditions are quite common in the analysed six cases; the case of Fonyód is especially interesting, as there the different settlements have quite different and unique handicraft traditions, while the central small town has no folk traditions. Despite it, the materialized traditions in the Zalaszentgrót case are quite similar both in the small town and its neighbourhood.

As there are a lot of materialized traditions; it seems to worth separately analysing handicraft products and food products (or cuisine). The latter has an eminent role in the Zalaszentgrót case: here local festival is based on escargot and wine, but also on a quite common Hungarian salt cake (pogácsa). Wine has local tradition, but escargot is completely unusual both in the Hungarian and in the local cuisine; they decided to use it, because in the last decades a French company 
started to produce escargot in the area. The case of Mezőtúr town shows when the small town has special and separated symbolic meaning and local image inside the micro region. Mezötúr image rooted on a materialised tradition. The most famous cultural heritage of the region is the pottery art of Mezőtúr, despite it other settlements of the micro-region do not have specific materialised traditions. Their traditions: handicrafts and gastronomy based on peasant culture, are not unique. Örség micro-region and its settlements have several materialized traditions such as handicrafts, traditional dishes, agro-food products. Overall symbolic meaning of the region as like as rural idyll is strengthened by these traditional goods. Some of them appear as a special characteristics of certain settlements, e.g. the pottery art for Magyarszombatfa. However the symbolic meaning of these materialised traditions is weaker than the overall symbol of the Örség. Symbolic image of Örség also gives special sense for common elements of peasant culture such as gastronomy, folk-art etc.

Natural value is also a quite typical local symbol. In most of our cases we found that landscape, or certain natural values became symbol of the place, thus gain important role in place-making. Despite it, there are few natural values which are visible also at the national level, or well-known internationally; a singular exception is the lake Balaton, but it is not linked directly to the Fonyód case.

Natural values are highly valued by locals, and as we saw in the case of Vasvár, locals aimed to develop it a symbol of the place, using a local, but nationally well-known Botanic Garden, as a local symbol. Also in the case of Fonyód, we found that local actors try to use the lake Balaton as a symbol of the place. In the Vasvár case it failed, because both locals and non-locals link the Botanic Garden to one certain village, and not to the area, while in the Fonyód case the lake can be linked to several other settlements, and regions, not only to this town and micro-region. While in the first case the natural value is too particular, in the other it is too general. One of the main element of Örség symbol is connected to the landscape. Örség landscape includes natural beauties, unique settlement structure and built heritage. In this case the landscape also has the meaning of rural idyll like other elements of local symbols, based on materialized traditions.

We had two cases, the Zalaszentgrót and the Örség case, which shows when the small town includes all the elements of regional symbol without specific characteristics. The settlements in both regions contribute to the symbolization of the place without monopolizing the process. In both cases all the settlements contribute to the image and the sense of place by their special and common characteristics. In the case of Mezőtúr micro region Mezötúr town has a separated unique symbol while the symbol of the entire micro-region is weakly connected to the image of the central small town.

Internationally known local symbols are very rare in rural Hungary (Pusztai, 2003). The symbol of Kalocsa micro-region such as the folk art tradition of colourful flower motifs and the paprika are Hungaricums and they are well known both internationally and nationally as Hungarian symbols. The lake Balaton, a symbol of the Fonyód district is also internationally well-known symbol of Hungarian tourism sector (Kabai, 2013).

Although most of the studied rural regions try to find nationally well-known local specialities to symbolise the place, Örség idyll is nationally very well known providing a strong symbol for the place, but such efforts were unsuccessful in the Vasvár and Zalaszentgrót case. In the first one they found locally known, and not specific symbols; like natural values and religious monuments. In the Zalaszentgrót case there are too much and too general symbols on the one hand, and both locally and nationally not accepted symbol (the escargot) on the other hand. Locals have organized an Escargot Festival since 2010, as there is the biggest escargot processing company of Central-Europe. Escargot consumption has no tradition neither in the local, nor in the Hungarian cuisine, which can be a reason why it cannot become a local symbol. Mezőtúr micro region also use nationally well-known local specialties to symbolise the place, both the pottery art of Mezötúr town or the Cuman origin of the region are nationally well known, but they have not strong unique sense. 
Maybe it is unexpected, but we found in several cases that local symbols were almost unknown locally, and completely unknown nationally and internationally, like in the case of Fonyód, or Vasvár; these cases show that the symbolization initiative failed already at the beginning of the process. Nationally and internationally unknown local symbols, in several cases are not characteristic enough, like wine or strudel - which can be found all over the country.

The publicity of the symbol is closely linked to the question, whether the symbol is accepted by the local inhabitants as a local characteristic tradition or natural value. The very strong symbols of Kalocsa are accepted by locals and these Hungaricums are valued also locally. The rural idyll symbol of Örség is strongly accepted by locals including newcomers. However the lack of local acceptance can be traced back to several factors: in the Vasvár, Mezőtúr and Fonyód case we found that also locals do not regard natural values as characteristics to the locality, although they highly value it. Also in the Vasvár case we found that local traditions are highly valued and accepted as local characteristic, but are not kept attractive enough; thus local traditions could not become symbol of the locality. In the Fonyód and Mezőtúr cases we see that there are conflicts among the different settlements, to define local symbol - later we will analyse in details this issue.

\section{Institutionalisation of place-making}

Local stakeholders and initiators collect and reconstruct image elements of the locality; they are the most important actors of the symbolization initiative, thus place-making (Lysgård, 2016). They shape local institutions; in the following we analyse their role, their networks and divergent interests in the process (Skerratt et al., 2013). Institutionalisation of place-making includes all the processes of local place-making. It contains the establishment of temporary organisations, the building of local networks, but also the organisation of events and other activities. We divided this dimension analysing the institutions of local place-making into the following sub-dimensions:

Tab 3. Institutionalization of place-making.

\begin{tabular}{|c|c|c|}
\hline Dimension & Sub-dimension & Values \\
\hline \multirow{4}{*}{$\begin{array}{l}\text { Institutionalization of place- } \\
\text { making }\end{array}$} & $\begin{array}{c}\text { Relation of the small town and its } \\
\text { surroundings }\end{array}$ & $\begin{array}{l}\text { centralized } \\
\text { egalitarian } \\
\text { contested }\end{array}$ \\
\hline & Location of the new organizations & $\begin{array}{l}\text { Local town } \\
\text { Local rural area } \\
\text { Non-local }\end{array}$ \\
\hline & Location of most important Events & $\begin{array}{l}\text { Local town } \\
\text { Local rural area } \\
\text { Non-local }\end{array}$ \\
\hline & Origin of human resources & $\begin{array}{l}\text { Local townspeople } \\
\text { Local rural people } \\
\text { Non-local }\end{array}$ \\
\hline
\end{tabular}

The relationship between the small town and the surrounding area seems to be decisive (Ebrahimzadeh et al., 2012) in the symbolization process. We defined four categories: centralized, egalitarian, and contested. The role of small towns in institutionalisation process can be analysed by the territorial position of small towns. The location of new organizations, new events, and network centres are also important characteristics. Similarly the origin of the most important actors of symbolization has to be analysed to understand the role of small towns in place-making. Finally the character of the rural small town and the surrounding region will be described in the following. Our aim is to find the common motives how do the characteristics of human resources of small town determine the approaches of image building, and to better understand the effect of bottom-up, and top-down etc.)

We found examples of centralized organization of place-making institutions in the Kalocsa and Fonyód cases. The symbolic meaning of the place and also the institutionalisation of image 
building in Kalocsa micro-region is centralised by Kalocsa small town. Most of the organisation aiming to present and strengthen the image of the place were established in the town. However, all villages have organisations for protecting local cultural heritage but most of them do not focus on image building. The local government of the rural small town established a non-profit organisation to lead micro-regional place-making including tourism development and image building. In the Fonyód case the centralization derives from the general organization of the institutions of the region. Most of the local institutions are located in the rural small town, and most of the decisions are made in the centre, although local events are organized all over the settlements. Most active stakeholders of the symbolization process are local townspeople and non-locals.

We have two examples of egalitarian organization of local place-making: Örség and Vasvár. The Örség area has a strong symbolic value, it represents the rural idyll in the Hungarian context and all the settlements of the area share this image. Some of the settlements also has own characteristic traditions, like the pottery art in Magyarszombatfa, but none of the individual specialities shadows the local image of the area. Therefore all settlements and their organisation participate in local place-making, they organise common events and promote themselves together. Egalitarian organization of local issues have a long tradition in the Vasvár area: the mayor of the central town shares the power with the mayors of the smaller settlements, and the mayors discuss with each other and representatives of local civic organizations, local entrepreneurs the relevant issues of the micro-region. Religious monuments, local natural values and historic traditions as local symbols are the results of the consensus of the local elite, both from the small town and the rural areas.

We found contested relationship among the settlements in the case of Mezőtúr and Zalaszentgrót. Contested images and symbols are resulted conflict both within the town and the micro-region. The contested situation in Zalaszentgrót derives from the fact that the area does not have wellknown traditions, or famous cultural, natural values and on the other hand the most important stakeholders of local development have latent conflicts. In this case the initiators of place-making are local rural people. The agreements are always the results of new and new negotiations. Mezőtúr town has a conflicting position in the symbolisation process of the micro-region. Initiators of place-making of Mezőtúr town purpose to strengthen and highlight the symbol of the town such as pottery in local place-making. They have capacity and knowledge and a strong network inside the town, e.g. they organise a Tourism Roundtable where they negotiate and plan the symbolisation process of the town and also of the micro region. Nevertheless all the other settlements intend to symbolise the place by Cuman past origin. Although they have a common symbol and civic organisation of the Cuman settlements started to organise a local network of civic organisations they do not have capacity and knowledge to replace the position of Mezötúr initiators in local place-making The most important organisations and the most important events relating to place-making take place in Mezőtúr town while the events and organisations of other settlements have weaker position in place-making.

\section{Marketing of the place}

This dimension includes all the goods and services used in symbolization and through which the sense of place can be reached for locals and also for outsiders. It comprises the good and services related to tourism such as accommodation, gastronomy, tourism sites, local food production and food products, and local events, but also other products which are linked to the region thus it includes all range of local goods and services which are connected to the locality and strengthen the symbolic meaning of the place Hopkins 1998).

Rural goods and services are available in all settlements in three cases: Vasvár, Zalaszentgrót and Örség. These cases show RGS can be offered across a whole area: attractions and accommodations are equally distributed, there is an equilibrium in the marketing of the location. 
Tab 4. Marketing of the location.

\begin{tabular}{ccc}
\hline Dimension & Sub-dimension & Values \\
Marketing of the location & Location of the RGS's & Town; \\
Surrounding area & Locally \\
Nationally \\
Internationally
\end{tabular}

Most of the rural goods and services, the main products of the case study areas are available in towns in the case of Kalocsa, Mezőtúr and Fonyód. In the case of Fonyód, the most known RGS are the lake Balaton, as a holiday resort. Settlements away from the lake shores can hardly benefit from this RGS. Although minor settlements continuously try to develop attractive RGS, their efforts fails. In the case of Kalocsa the most important events and museums and other attractions presenting the local symbols such as folk-art tradition and paprika production are situated in Kalocsa town all the other settlements do not have special RGS. However in the case of Mezötúr all settlements try to provide their own local RGS but the centre of promotion such as Tourinform Agency is situated in Mezötúr town thus all the local RGS are presented in this central small town.

It is worth noting that we did not find a case in which RGS would be available exclusively in a village. Although in the case of Örség region all the villages have a special RGS and some of them has particular symbolic meaning but all the RGS of the villages contribute to the common image and marketing of the region.

Most of the RGS in the analysed cases are available locally. It has two main reasons: on the one hand most of the RGS cannot be moved (like accommodations, landscape, monuments), on the other hand, most of the RGS are not well known outside the area, thus it does not worth to move them (like the dishes of local cuisine or local food products).

\section{Comparison of the cases}

The analytical framework serves to better understand how the characteristics of a rural small town determine the main elements of symbolization and marketing of a place through food products, events, tourism services, and to better understand how symbolization initiatives evolve in different contexts. In the following we compare the six cases focusing on the similarities and differences among them.

We found three types of place-making: the monopolistic model, in which the central town defines the symbol, and builds necessary institutions, using the human resources of townspeople, the inclusive model, in which actors aim at reaching a consensus about the symbol, and aim at cooperating in the symbolization process. The third type is a mixed type: in this case townspeople seems to have more influence on place-making, but the actors try to involve also the neighbouring settlements into the initiative.

The character of the symbol seems to be less influential on the symbolization process. Both nonmaterial and material traditions can be enough strong and successful symbol of the places.

The marketing of the place and the availability, or visibility of the place is typically international or at least national in the case of the centralized model, as our case studies show, while in the egalitarian and the mixed model, the marketing of the place and the symbol is weak, as a consequence of it also the availability covers mainly local areas.

Kalocsa and Fonyód are belonging to the monopolistic type. In these cases we see that the symbolization process could not became a medium of resistance: it offers nationally and internationally well-known symbols (Paasi, 2003) and disregards local ideas and needs. Kalocsa town monopolized the symbolisation process. All the elements of symbolic meaning are placed and presented in Kalocsa town even if they are originated from the surrounding villages too. The symbolisation process in Fonyód is similar: the central town tried to monopolize it, although it failed. While in the Kalocsa case the town successfully occupied and colonised the symbolic 
meaning of the micro region, in the Fonyód case it did not happen. The name Kalocsa is strongly linked to the well-known symbol of the micro-region, while the surrounding villages remained absolutely unknown, although those have the same folk-art heritage and paprika (food) production as the town has. The sense of place is linked exclusively to the town, which has a symbolic power inside the micro region and also externally. In the Fonyód case the monopolization was less successful; also the smaller villages could use the symbol, and some of the villages could build own symbols.

Tab 5. Comparison of the cases.

\begin{tabular}{|c|c|c|c|c|c|c|}
\hline Dimension & Kalocsa & Fonyód & Mezőtúr & $\begin{array}{l}\text { Zalaszent- } \\
\text { grót }\end{array}$ & Örség & Vasvár \\
\hline $\begin{array}{l}\text { The } \\
\text { symbolization of } \\
\text { place }\end{array}$ & Hegemon & Undefined & Undefined & Undefined & Consensual & Consensual \\
\hline $\begin{array}{l}\text { Similarity of } \\
\text { symbols across } \\
\text { the micro-region. }\end{array}$ & No & Yes & Yes & No & No & No \\
\hline $\begin{array}{c}\text { Coverage of the } \\
\text { symbol }\end{array}$ & Partial & No & Partial & No & Full & Full \\
\hline $\begin{array}{l}\text { Local view of the } \\
\text { symbol }\end{array}$ & Accepted & $\begin{array}{c}\text { Not } \\
\text { accepted }\end{array}$ & $\begin{array}{c}\text { Not } \\
\text { accepted }\end{array}$ & $\begin{array}{c}\text { Not } \\
\text { accepted }\end{array}$ & Accepted & Accepted \\
\hline $\begin{array}{l}\text { Institutionalization } \\
\text { of place-making }\end{array}$ & Top-down & Top-down & $\begin{array}{l}\text { Bottom-up } \\
\text { \& top-down }\end{array}$ & Bottom-up & Bottom-up & Bottom-up \\
\hline $\begin{array}{l}\text { Relation of the } \\
\text { small town \& its } \\
\text { surrounding }\end{array}$ & Centralised & Centralized & Contested & Contested & Egalitarian & Egalitarian \\
\hline $\begin{array}{l}\text { Location of the } \\
\text { new } \\
\text { organizations }\end{array}$ & $\begin{array}{l}\text { Exclusively } \\
\text { in the town }\end{array}$ & $\begin{array}{l}\text { Exclusively } \\
\text { in the town }\end{array}$ & $\begin{array}{l}\text { Mostly in } \\
\text { towns }\end{array}$ & $\begin{array}{l}\text { Mostly in } \\
\text { towns }\end{array}$ & $\begin{array}{c}\text { In all } \\
\text { settlements }\end{array}$ & $\begin{array}{c}\text { In all } \\
\text { settlements }\end{array}$ \\
\hline $\begin{array}{l}\text { Location of most } \\
\text { important Events }\end{array}$ & $\begin{array}{l}\text { Exclusively } \\
\text { in the town }\end{array}$ & $\begin{array}{l}\text { Both rural \& } \\
\text { urban parts }\end{array}$ & In towns & $\begin{array}{l}\text { Both rural \& } \\
\text { urban parts }\end{array}$ & $\begin{array}{l}\text { Both rural \& } \\
\text { urban parts }\end{array}$ & $\begin{array}{l}\text { Both rural \& } \\
\text { urban parts }\end{array}$ \\
\hline Human resources & Local town & $\begin{array}{l}\text { Local town } \\
\& \text { non-local }\end{array}$ & Local town & Local town & $\begin{array}{l}\text { Locals \& } \\
\text { newcomers }\end{array}$ & Locals \\
\hline $\begin{array}{l}\text { Marketing of the } \\
\text { location }\end{array}$ & $\begin{array}{l}\text { Unequal \& } \\
\text { intensive }\end{array}$ & $\begin{array}{l}\text { Unequal \& } \\
\text { intensive }\end{array}$ & $\begin{array}{l}\text { Equal \& } \\
\text { weak }\end{array}$ & $\begin{array}{l}\text { Equal \& } \\
\text { weak }\end{array}$ & $\begin{array}{l}\text { Equal \& } \\
\text { intensive }\end{array}$ & $\begin{array}{l}\text { Equal \& } \\
\text { weak }\end{array}$ \\
\hline $\begin{array}{l}\text { Location of the } \\
\text { RGS's }\end{array}$ & Town & Town & $\begin{array}{c}\text { All } \\
\text { settlements }\end{array}$ & $\begin{array}{c}\text { All } \\
\text { settlements }\end{array}$ & $\begin{array}{c}\text { All } \\
\text { settlements }\end{array}$ & $\begin{array}{c}\text { All } \\
\text { settlements }\end{array}$ \\
\hline $\begin{array}{c}\text { Areas of } \\
\text { availability }\end{array}$ & $\begin{array}{l}\text { National \& } \\
\text { international }\end{array}$ & $\begin{array}{l}\text { National \& } \\
\text { international }\end{array}$ & Local & Local & $\begin{array}{l}\text { Local \& } \\
\text { national }\end{array}$ & Local \\
\hline $\begin{array}{l}\text { Character of } \\
\text { place-making }\end{array}$ & Monopolistic & Monopolistic & Mixed & Mixed & Inclusive & Inclusive \\
\hline $\begin{array}{l}\text { Outcomes of } \\
\text { place-making }\end{array}$ & Established & Conflicting & Conflicting & Developing & Established & Developing \\
\hline
\end{tabular}

The character of the symbolization processes of the second type (inclusive) shows similarities with the characteristics of neo-endogenous development (Dessein et al., 2015; Halseth et al., 2010; Ray, 1998; van der Ploeg and van Dijk, 1995). The similarities lie on the one hand in the institutionalization of the initiatives: bottom-up development, eminent role of local stakeholders, on the other the emphasis on local cultural heritage and agriculture (van der Ploeg and Renting, 2004). As we saw, in several cases place-making initiatives are developed together with other rural development initiatives (Brunori and Rossi, 2000). The examples for the second type are Vasvár and Örség micro-regions. The two neighbouring areas has similar natural environment, also the settlement structure is similar. In Vasvár the symbolization process is 
governed by several local institutions, some of them located in the villages and only a part of them in the small town. Also the events are equally distributed across the area. The stakeholders are from the villages and not from the central town. Bottom-up initiatives and important role of agriculture or agriculture related traditions are characteristic in the egalitarian model. Similarly in the Örség region all settlements and their organisations are involved in place-making and most of the settlements used to participate in local events and they promote the region together. Here the most important actors are connected to the tourism and culture, we found bottom up initiatives such as the Network of Rural Accommodations of Örség, but institutional bodies like the National Park Directorate of Örség and local governments have important role in local place-making.

The third - mixed type - also shows elements of neo-endogenous development, although agricultural activity is less important in these cases. The main difference is related to the governance of the place and the lack of clear symbols use in the symbolization process. It is the most visible in the case of Zalaszentgrót, where there are several different symbols used in the symbolization initiative, these symbols are not well-known and not accepted neither locally, nor nationally. The case of Mezőtúr is different: here the symbols of each settlements are accepted within the settlement, but not at the micro-regional level. The contested nature of the symbols is also reflected in the institutions of symbolization.

Our case-study analysis shows three different types of the outcomes of place-making process. Outcomes of place-making can be established, developing and conflicting. Outcome of placemaking is established when a characteristic and locally accepted symbol of place has been selected and the institution of place-making are well-organised and the marketing of the place results a strong place image and its related RGS. The cases of Kalocsa and Örség represent this type and also show that an established outcome of place-making can be resulted by very different ways. Thus both the monopolistic and inclusive type of place-making could result established outcomes.

The outcomes of place-making is developing if the process is not finished at all, the symbol is under selection and it may change, the institutions and networks are evolving and especially the image of the place is weak and unknown outside the region even if it is locally accepted. The type of developing shows a significant local demand for place-making with several outcomes which can be the base of a strong local image. This type is represented by Zalaszentgrót and Vasvár cases. These cases also show that the demand for place-making is strongly connected to the level of community integration.

The outcome of place-making is conflicting when neither the symbol nor the institutions and activities are agreed and accepted regionally. In this type several settlements of the region have special symbol and special RGS and they create particular institutions for place-making. Sharp competitions between settlements for the leading position of place-making is appeared in this type. Fonyód and Mezőtúr cases are very good examples for this type. Both micro regions contain more than one small towns and it seems important concerning the outcome of place-making.

\section{Conclusions}

We found that the place-making process became established or developing, in cases where the symbolization process were monopolistic or inclusive, thus territorial innovations can be realized in both cases. Although the outcome was similar, the paths leading to the similar outcomes are different. In the case of inclusive place-making processes consensual symbolization process initiated and managed by local actors lead to the result by developing events throughout the area. In the case of the monopolistic place-making process a hegemon symbolization of the place results that there is a characteristic and shared symbol of the place, organised in a top-down process.

Our results show that conflicts make territorial innovations difficult, or impossible. In the cases where the place-making process was mixed, we did not find established place-making, only conflicting and developing ones, but even a deeper analysis of the developing one shows, that 
the place-making process is in a very preliminary phase. Undefined symbolization process also leads to the failure or the preliminary status of the place-making process.

If we compare the character of the micro-region or district and the outcome of the place-making process, we see that only the centralized district, with one urban centre could develop an established place-making process under centralised institutions and monopolistic character. The one-centred micro-regions with established or developing place-making process were more inclusive. Place-making is more difficult in multi-centred districts: in these cases, mixed methods seem to be more fruitful. Unfortunately, we had no example of the multi-centred districts following the inclusive model.

Our cases show that the role of small town in place-making does not depend on the economic and demographic characteristic of the towns. Even the relevance of tourism does not have strong effect on place-making process. Our cases prove that the role of small towns in place-making significantly depends on the territorial position of small town in the region such as its relation to their surroundings. Both hegemonic and inclusive place-making can be found in one-centred regions while multi-centred pole regions are significantly characterised by the conflicting type. The symbolic power of small town is also strongly determining its role in place-making, unique and too strong town symbol leads to conflicting place-making process while a strong but comprehensive symbol even if it is originated especially from the town results an established place-making. In addition the weak symbolic power of the small town results inclusive placemaking where particular characteristics of the settlements including the small town contribute to a common symbol.

Our cases show that there are several configurations of given factors, institutionalization and symbolization initiatives, which create different pathways of place-making leading and also different results of place -making. One of the most interesting questions concerning these initiatives are about the future development of place-making. Only future research may show, which settings of the different place-making processes can result a long-lasting sustainable symbolization based development of the place.

\section{Acknowledgement}

Both researchers were supported by the European Union and the State of Hungary, co-financed by the European Social Fund in the framework of TÁMOP 4.2.4. A/2-11-1-2012-0001 'National Excellence Program' \& the Bolyai János Postdoctoral Scholarship of the HAS.

References

[1] Bessière, J. (1998). Local Development and Heritage: Traditional Food and Cuisine as Tourist Attractions in Rural Areas. Sociologia Ruralis 38(1), 21-34. Doi: 10.1111/14679523.00061.

[2] Brunori, G. \& Rossi, A. (2000). Synergy and Coherence through Collective Action: Some Insights from Wine Routes in Tuscany. Sociologia Ruralis 40(4), 409-423. Doi: $10.1111 / 1467-9523.00157$.

[3] Bublik, B. \& Nyeste, A. (2014). Fejlődő és leszakadó járások Magyarország társadalmigazdasági profilja. http://old.gvi.hu/data/papers/regio_2013_elemzes_140804_.pdf 2014.

[4] Castells, M. (1997). The Power of Identity: The Information Age: Economy, Society, and Culture. Hoboken (NJ): John Wiley \& Sons.

[5] Cloke, P. (1997). Country backwater to virtual village? Rural studies and "the cultural turn." Journal of Rural Studies. 13(4), 367-375. Doi: 10.1016/S0743-0167(97)00053-3.

[6] Cloke, P., Goodwin, M. \& Milbourne, P. (1998). Inside look- ing out, outside looking in. Different experiences of cultural competence in rural lifestyles (pp. 134-150). In: Boyle, P. \& Halfacree, K., eds., Migration into Rural Areas: Theories and Issues. Chichester: Wiley. 
[7] Csurgó, B. (2014). A vidék nosztalgiája : kulturális örökség, turizmus- és közösségszervezés három észak-alföldi kistérségben. socio.hu 4, 1-20. Doi: 10.18030/SOCIO.HU.2014.2.1.

[8] Csurgó, B. \& Megyesi, B. (2015). Local food production and local identity: Interdependency of development tools and results. socio.hu 5, 167-182. Doi: 10.18030/socio.hu.2015en.167.

[9] Dessein, J., Battaglini, E. \& Horlings, L. (2015). Cultural Sustainability and Regional Development: Theories and practices of territorialisation. Abingdon: Routledge.

[10] Dunn, K. M., McGuirk, P. M. \& Winchester, H. P. (1995). Place Making: the Social Construction of Newcastle. Geographical Journal 33(2), 149-166. Doi: 10.1111/j.14678470.1995.tb00691.x.

[11] Ebrahimzadeh, I., Tayyebi, N. \& Shafei, Y. (2012). Functional Analysis of Small Towns Economic Role in Rural Development, Case Study: Zahedshahr, Iran. Journal of Service Sciences and Management. 5(3), 269-279. Doi: 10.4236/jssm.2012.53032.

[12] Halfacree, K. (2007). Trial by space for a "radical rural": Introducing alternative localities, representations and lives. Journal of Rural Studies. 23(2), 125-141. Doi: 10.1016/j.jrurstud.2006.10.002.

[13] Halfacree, K. (1995). Talking about rurality: Social representations of the rural as expressed by residents of six English parishes. Journal of Rural Studies. 11(1), 1-20. Doi: 10.1016/07430167(94)00039-C.

[14] Halfacree, K. (1993). Locality and social representation: Space, discourse and alternative definitions of the rural. Journal of Rural Studies. 9(1), 23-37. Doi: 10.1016/07430167(93)90003-3.

[15] Halseth, G., Markey, S. P. \& Bruce, D. (2010). The Next Rural Economies: Constructing Rural Place in Global Economies. Wallingford: CABI.

[16] Heffner, K. \& Solga, B. (2006). Small towns as local economic centres in rural areas. Bulletin of Geography. Socio-Economic Series 6, 77-88. Doi: 10.2478/2452.

[17] Hopkins, J. (1998). Signs of the Post-Rural: Marketing Myths of a Symbolic Countryside. Geografiska Annaler. Series B Human Geography 80(2), 65-81. Doi: 10.1111/j.04353684.1998.00030.x.

[18] IImonen, K. (2015). The Role of Culture in Regional Development Work - Changes and Tensions (pp. 79-95). In Go, F. M., Lemmetyinen, A. \& Hakala, U., eds., Harnessing Place Branding through Cultural Entrepreneurship. London: Palgrave Macmillan UK.

[19] Jones, O. (1995). Lay discourses of the rural: Developments and implications for rural studies. Journal of Rural Studies 11(1), 35-49. Doi: 10.1016/0743-0167(94)00057-G.

[20] Kabai, G. (2013). A Balaton Kiemelt Üdülökörzet mozgástere a fejlesztéspolitika rendszerében 2006-2012 között. DETUROPE - Central European Journal of Regional Development and Tourism. 5(2), 1-23.

[21] Kivitalo, M., Kumpulainen, K. \& Soini, K. (2015). Exploring culture and sustainability in rural Finland (no paging). In: Dessein, J., Battaglinu, E. \& Horlings, L., eds., Cultural Sustainability and Regional Development: Theories and practices of territorialisation. New York: Routlege.

[22] Kovách, I. (2012). A vidék az ezredfordulón. Budapest:.Argumentum Kiadó.

[23] Kvale, S. (1994). Ten standard Objections to Qualitative Research Interviews. Journal of Phenomenological Psychology 25(2), 147-173. Doi: 10.1163/156916294X00016.

[24] Lysgård, H. K. (2016). The "actually existing" cultural policy and culture-led strategies of rural places and small towns. Journal of Rural Studies 44(1), 1-11. Doi: 10.1016/j.jrurstud.2015.12.014. 
[25] Mormont, M. (1990). Who is rural? or How to be Rural: Towards a Sociology of the Rural (pp. 21-44). In Marsden, T., Lowe, P. \& Whatmore, S., eds., Rural Restructuring. London: David Fulton.

[26] Paasi, A. (2003). Region and place: regional identity in question. Progress in Human Geography 27(4), 475-485. Doi: 10.1191/0309132503ph439pr.

[27] Phillips, M. (2005). People at the centre? The contested geographies of gentrification (pp. 317-352). In Phillips, M., ed., Contested Worlds: An Introduction to Human Geography. Aldershot: Ashgate.

[28] Phillips, M. (1993). Rural gentrification and the processes of class colonisation. Journal of Rural Studies 9(2), 123-140. Doi: 10.1016/0743-0167(93)90026-G.

[29] Pusztai, B. (2003). Megalkotott hagyományok és falusi turizmus (pp. 9-21). In Pusztai, B., ed., Megalkotott hagyományok és falusi turizmus Tourism: A pusztamérgesi eset. Szeged: JATE Press.

[30] Radcliffe, S. A., ed. (2006). Culture and Development in a Globalizing World: Geographies, Actors and Paradigms. Abingdon-on-Thames: Routledge.

[31] Ray, C. (2006). Neo-endogenous rural development in the EU (pp. 278-291). In Cloke, P., Marsden, T. \& Mooney, P., eds., Handbook of Rural Studies. Thousand Oaks, CA, SAGE.

[32] Ray, C. (1998). Culture, Intellectual Property and Territorial Rural Development. Sociologia Ruralis 38(1), 3-20. Doi: 10.1111/1467-9523.00060.

[33] Skerratt, D. S., Andersson, P. K., Sjöblom, P. S. \& Marsden, P. T. (2013). Sustainability and Short-term Policies: Improving Governance in Spatial Policy Interventions. Farnham: Ashgate.

[34] van der Ploeg, J. D. \& Renting, H. (2004). Behind the "Redux": A Rejoinder to David Goodman. Sociologia Ruralis 44(2), 234-242. Doi: 10.1111/j.1467-9523.2004.00272.x.

[35] van der Ploeg, J. D. \& van Dijk, G. (1995). Beyond Modernization: The Impact of Endogenous Rural Development. Assen: Van Gorcum. 